\title{
Some considerations on monasticism according to Father André Scrima
}

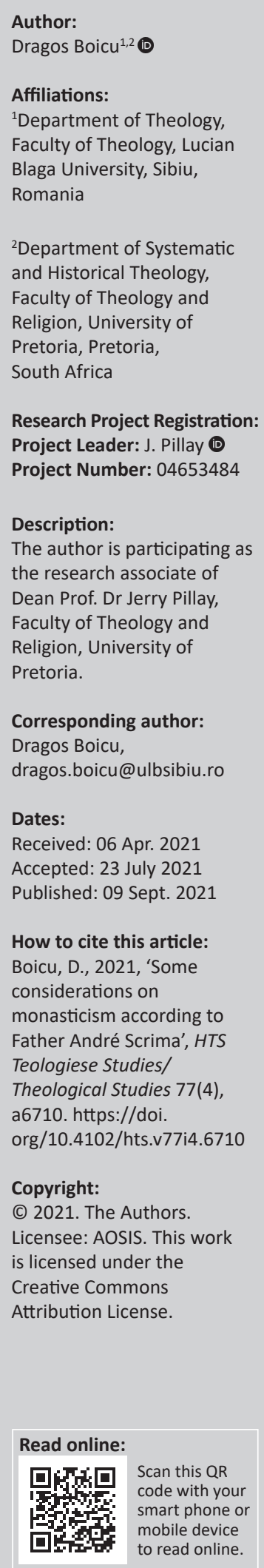

Father André Scrima emphasised in his works the importance of monasticism as an inward phenomenon of the church, and he even believed that the Orthodox Church can be considered a 'monastic' church, given that monasticism is itself ecclesial. Trying to explain this ecclesial function, Father Scrima developed a unique, fresh vision regarding the role that the monk had throughout history, and this article sought to summarise some of these observations as they emerged from the writings of Father Scrima.

Contribution: The article focuses on Father Scrima (1925-2000) and argues that this remarkable Romanian theologian is often overlooked. He was gifted with an incredible memory and an outstanding capacity to bring together information from different fields of knowledge - the so-called classical culture - with universal cultural elements, patterns, traits or institutions that are common to all human cultures worldwide, presenting them in a theological interpretation.

Keywords: André Scrima; Orthodox Church; Eastern Christianity; monasticism; monk.

\section{Some biographical data}

As a student at the Faculty of Philosophy (and in parallel at the Faculty of Mathematics and Physics), André Scrima was noted for his contributions to the field of optics, but his life took a strange turn when he met Father Ivan Kulîghin. Father Kulîghin was a refugee hieromonk who between the years 1945 and 1947 animated the spiritual adventures of the Christian Association as 'The Burning Bush' (Ică 2004:471-475) - a reference to the event described in Exodus 3. This encounter would forever change the life of the young student, who subsequently embraced the monastic way of life. However, the limitations of this context thin out the results of the scholarly research of this restless interpreter, who was always looking for an elementary rationality (Boicu 2020:439-440).

A series of unexpected encounters would lead him out of Romania on a very winding journey to India (1957-1959). The experience he acquired traveling the world, encountering other cultures, and the inner strength and disposition to see the common traits of the geographical, spiritual and cultural spaces of other religions made him always and everywhere mindful of the signs of the same universal calling, which is addressed to all humankind. He acted as the personal representative of the Ecumenical Patriarch Athenagoras to the Second Vatican Council(1963-1965), and afterwards he spent almost 20 years in Lebanon teaching at the French University of Beirut (1968-1989). He was also the founder of the Deir El-Harf Monastery in Lebanon. In 1995 he returned to Romania for good, spending the last five years of his life there.

A monk, professor of religious comparative studies, he was first a traveller on the path of the Eastern Christian tradition seeking the boundlessness of God but also a traveller through the geographical, spiritual and cultural spaces of other religions. He was always and everywhere mindful to the signs of the same universal calling, which is addressed to all humankind.

Impressed by the requirements (Buda 2016:415-418; Streza 2015:75-80) of the ascetic way of life (Oancea 2006:8-10), André Scrima responded to a genuine monastic vocation, embracing a way of life deeply anchored in the Eastern monastic tradition (Brusanowski 2014). Moreover, he remained preoccupied with understanding his own mission as a monk and became a connoisseur of the monastic phenomenon (Ielciu 2008:224).

As an Orthodox monk and spiritual traveller, Scrima considered that scientific rigor, critical thinking and careful investigation sustain and prepare the astonishment before which divinity

Note: Special Collection: Lucian Blaga University, Sibiu, Romania, sub-edited by Daniel Buda (Lucian Blaga University) and Jerry Pillay (University of Pretoria). 
sheds its meanings. For André Scrima, researching the path of hesychasm and the history of monasticism was to research and penetrate the meaning of his own commitment as a monk. It meant researching the experience (spiritual, intellectual, existential) of a very long line of prayer 'professionals', of travellers in God. The landmarks André Scrima invokes are relevant to the way that he conceived, built and assumed his destiny. That is why it can be said that monasticism remains the discreet foundation of his entire existence. Over time, it becomes a way of being, a key to understanding the great spiritual traditions. Monasticism could be seen as the special rhythm of his own life, a recurring subject of his writings. Thus, the theoretical texts of Father Scrima on monasticism can be seen both as a confession of his own life and as an example of an integral, radical commitment to spiritual itinerancy (Tofan 2019:60).

This itinerancy and preoccupation with embodying the monastic life are combined in Scrima's work of spiritual guidance for the small monastic community reborn in the monastery of Saint Georges de Deir-el-Harf, $34 \mathrm{~km}$ east of Beirut. Here, he became involved in reorganising the community, dedicating himself to the formation of the young monks of this monastery.

Concerned with highlighting the monk's place in the world and the meanings of monasticism in a society strongly affected by the hostile attitude of the communist regime towards the religious phenomenon (Toroczkai 2016:403-407), André Scrima wrote a series of texts and essays dedicated to these topics. Amongst them is the essay 'Prolegomene la o ontologie a stadiului monahal - Bíos à $\gamma \gamma \varepsilon \lambda ı \kappa \tilde{c} \varsigma^{\prime}$ [Prolegomena to an ontology of the monastic condition - Bíos à $\gamma \gamma \varepsilon \lambda \iota \kappa \tilde{\omega} \varsigma]$, written sometime between 1950 and 1956, most likely when the young André was still a novice and had not yet received the monastic tonsure. To this interesting text are added two studies published between 1961 and 1962: 'Le monachisme orthodoxe: histoire, traditions, spiritualité' (written most probably for a collective volume about monasticism) and 'À l'intérieur du mystère de l'unité: le moine' (published in the volume Le mystère d'unité. T. 2. L'Église en plénitude, col. Cahiers de La Pierre-qui-vire 18, Desclée de Brouwer (DDB), Paris 1962:186212). Three decades later, in 1996 André Scrima published the volume Timpul Rugului Aprins: Maestrul Spiritual în Tradiţia Răsăriteană [The Age of the Burning Bush: The Spiritual Master in the Eastern Tradition]. In this book he insists on the role of spiritual fatherhood and tangentially describes the monastic life and its demands, as it unfolded in the Antim Monastery in Bucharest, where he began his monastic life. To these texts are added the numerous handwritten notes he left, which were published posthumously. From these texts emerge several recurring ideas that allow us to reconstruct a synthesis of Father Scrima's vision regarding the place of the monk in the church and in the world.

\section{Who or what is a monk?}

Before presenting the place of the monk in his particular vision, it is necessary to clarify what or, better said, who is the monk for Father Scrima. In all the mentioned texts, André Scrima tries to capture the essence of monasticism as a spiritual phenomenon, offering a series of definitions that describe the monk starting from a certain attribute or requirement. Such an explanation starts from the etymological notion (Scrima 2008):

The monk is, by definition, the unitary creature: his very name 'monos' - the one - shows us. He is destined for simple life, in the integrity of his being, like angels who are simple creatures who do not suffer the breaking of their lives by living in lust. (p. 52)

To be a monk means ipso facto, to have accepted the very deep unity of your being in yourself and yours with God: therefore, with all those who are like you. (p. 110)

Therefore, the emphasis is not on loneliness or seclusion but on unity, and the monk knows the intimate secret of his name, he knows that he is not fully himself except in the new unity - so personal - with all' (Scrima 2017:25). While professing faith in the Holy Trinity and recognising Christ's redemptive work, he can only (Scrima 2017):

$[H]$ ave one purpose: unity, to the glory of God. And, indeed, because he tends there with all his being, he will be called - by an equivalent term -'monachus': a name suitable for his vocation, unifying and one, for the gift of the (Holy) Spirit and at the same time for the gift of self. (pp. 26-27)

In Father Scrima's vision, this vocation is universal, proper to every Christian because he 'testifies that he is destined for unity with his brothers insofar as he clings to Christ', and from the moment he 'dedicates himself to this union, to the always expandable limits of his freedom, he will become a living sign of union, monah (monk)' (Scrima 2017:26).

In fact, this is an idea that Scrima (2008) frequently highlights by showing that:

$[I] \mathrm{n}$ the Orthodox Church we consider that there is no clear dividing line between the life of the monk and the Christian life in general. Everyone is bound to rise as high as possible to the ideal of perfection; each is bound to fight for their cleansing of passions and for the acquisition of virtues, which culminate in love. It is not a special qualitative difference, but only a gradual one between the Christianity [Christian life] accomplished by the laity and the one that the monks have to accomplish. (p. 268)

Therefore, the monk embodies in a much more intense way the universal vocation of the church, the call to become a child of God by grace. Thus (Scrima 2008):

$[T]$ he monk is a man whom the new life, the new being who begins at baptism, fills in such a way that there is no room left in him for anything else, for the ways of the 'old man', of 'this world'. (p. 27)

As a result of Christ's redeeming work, the 'new man' is called to exercise his mission of intercessor, which was given to him at the creation of the world, but its realisation was interrupted by the original sin. The Christian has the vocation to reiterate (but in reverse order) the five mediations already accomplished by Jesus Christ: between the sexes, between 
paradise and the inhabited world, between heaven and earth, between intelligible and sensible, but also between God and his creation (Thunberg 1999:74-85). Following the logic of St. Maximus the Confessor, Father Scrima repeatedly emphasises the vocation for unity of Christians in general and of monks in particular: 'The monk remains an exemplary case, a “paradigm" of Christian unity' (Scrima 2017:21).

And the convergence towards unity, constitutive of the monk, will coincide in its point of fulfilment, as expected, with the mystery in which it has its origin: it is the Passion of the Lord Jesus Christ for the unity of all (Scrima 2017:27).

Therefore, the inner unity of the Christian in general and of the monk in particular is based on the sacrifice on Golgotha (Scrima 2008):

[B]ut the monk, risen with Christ, entered with him the city of angels; the monk, like Christ, with Christ and in Him, as master to all creation, he regained Adam's rights over the cosmos, he participates in the sovereignty of Christ over creation; but, precisely because of this, he can no longer exercise a right of property in the manner of the Adam's sons. (p. 43)

However, to participate in these 'rights', every Christian and especially the monk must harmonise their external manifestations with the inner experience, achieving even at this level a unity (Scrima 2008):

$[P]$ recisely by the fact that it is a unity of spirit and action (and not a 'hypocrisy' or a helpless pseudo-holiness) we have the sign and proof of the presence [of a perfect Christian]. (p. 60)

Father Scrima (2017) emphasises that in the monk's case:

$[H]$ is duty towards unity is more radical because it is inherent in his vocation, that is, in his new being in Christ. He testifies about it through the place of insertion in the Church he chose; through his capacity to also symbolise the Church. (p. 25)

Moreover, by unifying the self (the maximum coherence of facts with spiritual convictions) he achieves simplicity (simplicitas) and angelic order or 'inner integrity' (Scrima 2008):

[T] he monk becomes whole by the inner union of the mind with the heart, (the union) of these two centres separated by sin, but reconciled by the continual perseverance of in Jesus prayer. (p. 52)

As a result of this effort, the monks become 'fellow-citizens with the angels, but not angels themselves'. This is the ideal of monastic life, and that is why every monk (Scrima 2003):

$[A]$ ims to embody in the Church the 'angelic life' (an expression synonymous in the Eastern Church with that of the 'monastic way'), to announce the signs of the coming Kingdom, mysteriously present from now on. (p. 37)

Father André Scrima highlights this emphasis that Eastern spirituality lays on the 'angelic likeness' adopted by the monks when they take the three vows, which are seen (Tofan 2019):

$[I] \mathrm{n}$ a crescendo aimed at self-expropriation in order to reveal the divine fullness: if virginity has the meaning of giving up human relations in the broadest sense and the limitations of biological 'life', poverty means giving up the human need of having, and, finally, obedience means giving up being, so that the person is fully delivered to the Spirit, which 'fulfils one's personality'. (p. 62)

Therefore, the monks are considered 'in the Orthodox Church

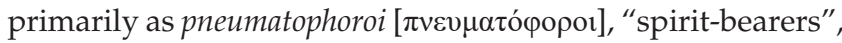
"inspired by God" and the monastic life is considered bios

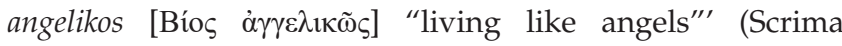
2008:210). The desire to resemble angels does not mean that they claim angelic status but rather presupposes humility:

They are men, and their irony does not spare those who claim to have become angels. They know very well that man is 'neither an angel nor a beast' and that 'he who wants to pretend to be an angel turns out to be more of a beast'. (p. 36)

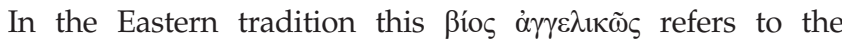
integration of the monk's life into the liturgical life of the church. The voluntary commitment to the three vows and the inner unification transforms the monk into a "liturgical being" par excellence, one who glorifies God incessantly and is incorporated with all his being into the death-resurrection of Christ' (Scrima 2008:352). On another occasion, Scrima (2017) considers that:

[I]t is natural for the monk to be, in the Church, a liturgical being par excellence. [...] He lives the liturgical mystery as an integral content of his life and a radical model of his contemplation. (p. 34)

Somewhat complementary, by virtue of his resemblance to angels, the monk of Eastern traditions is also considered 'a hymnological and contemplative being by definition, whose "noetic sky" (as the Sinaites say) is reached in the balance of his inner discourse and the liturgy of the Church' (Scrima 2008:367).

This idea is even better highlighted by Scrima (2008) when he shows that:

$[T]$ hrough doxology, the monks fulfil the angelic liturgy, realised in a mystic way, already present among us. Through virginity, they are the foreshadowing of the resurrected life (after the Resurrection), begun in Christ from this very instant: si consurrexistis cum Christo. They realize the perfect community,

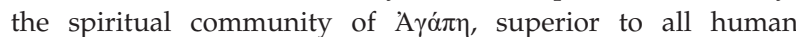
communities. (p. 25)

\section{The place of the monk in the church and in the world}

From a chronological point of view, the emergence of monasticism took place soon after the end of the Great Persecution of Diocletian, although the existence of ascetic communities has been attested since the middle of the 3rd century (Chifăr 2014:179-200). However, it is considered that (after the year 313) (Scrima 2008):

$[M]$ onasticism appears at this precise moment in order to embody and to affirm the essential incompatibility between the two cities [earthly and heavenly]. The monks, it was said, went in the wilderness in search of a heroism that ordinary Christian life no longer contained. (p. 34) 


\section{Therefore:}

[T] his antithesis between the two cities - the one in heavens, towards which we are heading, and the one on earth, which we have left or, rather, which we leave over and over again - is constitutive for the existence of the monk, but this is due first of all to the fact that (the antithesis) is constitutive for the existence of the Christian in the world. (p. 27)

If we were to understand the withdrawal from the world strictly as a means of satisfying the thirst for herosim (Scrima 2008):

[I]t means deeply ignoring the essence of monasticism. It should not be sought in the moral order, nor in the individual concern for salvation, but, let us say, in the ontological order. What exists, at least in a germinal stage, in any baptized person, in the monk has reached such a development that this new being is also expressed and manifested outside. The incompatibility of the two cities, the abandonment of the earthly city and the transition into the heavenly city meant martyrdom, which is only the last consequence, the full bloom of baptism, the entry into the monastic state. (p. 34)

This vision is presented a little more clearly by Scrima (2003) when he states that:

$[W]$ e, the people of today, find it difficult to overcome the doubt: after all, we can ask ourselves if the voluntary withdrawal of the monks into the wilderness was just a flight from Christian duty? Weren't they somehow moving away from the Church and its evangelical work? From the beginning, the monastic wilderness reassures us, in this respect, by its word and example: it is by no means about leaving the bosom of the Church, but on the contrary, it is about advancing deeper and deeper into the Church, until it reaches its heart. Far from being a collective escape or an adventure outside the community, early monasticism embodies and proclaims the responsibility of the baptized in this world until the coming of the Lord, lived on the extreme boundaries of dedication. Monasticism remains the highest school of the mystery of Christian mercy. (p. 27)

On the other hand, not even the desert is for the monk 'the physical guarantee of solitude, isolation or the most suitable place for contemplation, but a battle arena', a space of confrontation with one's own shortcomings, but also 'the continuation of the Quarantania desert, the almost compulsory meeting with the prince of this world' (Scrima 2008:107).

That is why we must not have the impression that the monks (Scrima 2004):

[L]eft behind one world to enter another of the same order. It could rather be said that they 'opened' the latter to the absolute coming of God, therefore to a fullness of meaning, simultaneously transcendent and immanent, which manifests the Lord Jesus Christ as the living centre of being. (p. 151)

Therefore, for Father André Scrima (2003), the place of monasticism is not on the outer edges of the church; on the contrary, it occupies a central place, a top place, being an integral part of the church, and therefore he dares to assert that:

[T] he Orthodox Church is considered a 'monastic' Church by virtue of the fact that, in its view, monasticism is itself ecclesial
[...] assumed and oriented by the very model of the Christian life, (monasticism itself) assumes and guides this life too. (p. 24)

The central place of monasticism in the church is apparent from the very fact that monastic life clearly and beyond doubt reveals the attributes of the church. That is why Father Scrima (2017) considers that:

[I] t would not be an exaggeration, therefore, to see in monasticism a place of manifestation of the inner being of the Church and its unity: we would even be tempted to speak of an 'ecclesiophany' that would only assume, to another degree of transparency, the ecclesiophany to which every baptized person is a bearer [...] But does the monastic vocation of manifesting the Church actually have a message to proclaim at the level of the realities on which the ecumenical meeting is based and through which the Christian mystery reaches the world? (p. 32)

The connection between monasticism and the church is even more clearly highlighted by Father Scrima (2008) when he shows the purpose of this perfect vocation:

Monasticism will therefore always retain its function in the Church, a function which is not related to a certain need that arose in a specific era of Church history, nor is it likely to disappear or transform; the monks will have their role in the life of the Church as long as it is on earth: that of keeping open the gate of communication between heaven and earth, the gate through which angels enter and leave, through which the Church attends and participates in the liturgy and the life of the heavenly city. (p. 49)

The intensive character with which the monk lived the Christian life in the desert is seen by Scrima (2008) as the most appropriate response to the tension created by the antithesis of the two cities, on which occasion he again highlights the 'function' of monasticism:

Since most members of the Church are at the same time members of the earthly city and exercise in it their rights as citizens - of course, legitimately - the role, the function of monasticism in the Church seems to us to be this: to assert the membership of Christianity in the city of angels, to assert here its rights there, implementing them. As long as the Church is on earth in its members, the monks have a certain task - they, who, without ceasing to belong to the Church, are now members of the city of angels - to keep the Church open to the city of angels, to keep it in communication with the Church of Heaven and the New Aeon. It means not understanding anything about monasticism if you believe that the monks are running away from the Church of the faithful because it no longer satisfies their aspirations for perfection or heroism. (p. 47)

Placing monasticism at the confluence of the two cities earthly and heavenly - Father André Scrima also focuses on the itinerant condition of the monk and considers that monastic life began as a kind of variation on the theme 'to become a stranger to this world', when the church and the world became too familiar with each other, the church becoming sedentary and Constantine the Great accustoming the world to its presence as a social, if not political, institution. Then came 'the exit towards the dimension of the strange and the stranger: the monk was essentially a stranger of this world' (Scrima 1996:33). 
The idea of itinerancy reflects even better the 'apostolic' dimension of monasticism, which 'finds its fulfilment in the apostolate, and moreover, the monk turns out to be the "apostolic man" in the highest degree' (Scrima 2003:29). As an apostle (Scrima 1996):

[T] he monk is an envoy sent on the way, he is launched on this path without being offered a precise earthly destination, that he should reach to settle in, the monk is an essential envoy, a foreign messenger. (pp. 89-90)

To further emphasise the idea of itinerancy, Father Scrima (1996) likens the monk to the angel who:

[S]tands as a messenger (sedebit solitarius et tacebit: the passage is consumed beyond silence; 'stands' and 'passes'). He's a steady envoy. So, it's a paradoxical combination of itinerance and sedentariness. The monk is steadfast only as long as he keeps moving, 'mobilized', 'on the way', refusing any densification, any solidification (including that, too familiar, of his presence). (p. 48)

This itinerancy seems to be for Father Scrima (1996) an opening to the hesychastic life that characterises Eastern monasticism:

The monk, the foreign envoy, is simultaneously a traveller and a sedentary, a 'standing person': that is, exactly the hesychastic position, which opens to others and, above all, opens itself to the zenith. Such a reading actualizes the very position of the hesychast: sedebit solitarius et tacebit. He is the one who stands and is, at the same time, in perpetual transition: we are dealing here not with an oxymoron, but with an absolutely necessary complementarity in our conditions of chrono-spatial finitude. Given the structure of our physical condition, in order to be stable, it is mandatory to be on the move, in motion: 'whoever thinks he stands must be careful not to fall' (1 Cor 10:12). 'Standing' here means inner realization, not only within the personal being, but within the spiritual being; as such it means extension, in spirit, beyond the limits of the individual person: it is, at the same time, a winding and an unfolding. (p. 82)

Or, as Scrima (2003:75) states in another place, for the monk 'stability is only the outward form of an ascending movement'.

Therefore, the monk is by definition a perpetual traveller, who has here no 'abiding city' (Heb 13:14) but is always on the way; he is a 'nomad', a wanderer, a gyrovague.

\section{Conclusion}

Although Father André Scrima was a monk and a connoisseur of monastic life, it was difficult even for him to define monastic spirituality because it largely overlaps with that of the church. What is certain is that ' $[y]$ ou do not enter mentally into monasticism to apply methods of individual perfection, but to assume the full and ecclesial meaning of the Christian life' (Scrima 2004:230-231). Moreover, the monastic life is the 'archetype', the fullness to which the Christian participates in the evangelical virtues. In fact, the church does not raise barriers between laypeople and monks, when, embarking on the same search, they discover themselves at the same distance from the living infinity (Scrima 1996:133). Therefore (Scrima 2003):
[I]n the East, the monk never had a 'clerical' status; only by exception does he become a priest. The monastic vocation is a vocation in itself. You become a monk to remain a monk to the end, all your life. The monastic vocation expresses this eschatological search of God in which all the elements of the notion of hesychasm come to be inscribed. (p. 81)

Through their vocation, monks emphasise the mystery of the church (Scrima 2017:43) and 'internalize' the world, the secular life, in order to integrate it spiritually in the fullness of its beginnings (Tofan 2019:69). That is why André Scrima considers monks essential to this world, emphasising that they are more necessary to the world than scientists, generals or politicians. For they are the salt of the earth that protects the world from decay (Scrima 2008:25).

\section{Acknowledgements Competing interests}

The author declares that he has no financial or personal relationships that may have inappropriately influenced him in writing this article.

\section{Author's contributions}

D.B. is the sole author of this article.

\section{Ethical considerations}

This article followed all ethical standards for research without direct contact with human or animal subjects.

\section{Funding information}

This research received no specific grant from any funding agency in the public, commercial or not-for-profit sectors.

\section{Data availability}

Data sharing is not applicable to this article as no new data were created or analysed in this study.

\section{Disclaimer}

The views and opinions expressed in this article are those of the author and do not necessarily reflect the official policy or position of any affiliated agency of the author.

\section{References}

Boicu, D., 2020, 'Epiphany and otherness in the vision of Father Andre Scrima', Review of Ecumenical Studies 12(3), 439-457.

Brusanowski, P., 2014, 'Dreptul ctitoricesc [Founders rights]', in M. Păcurariu \& N. Edroiu (eds.), Monahismul ortodox românesc: Istorie, contribuţii şi repertorizare [Romanian Orthodox monasticism: History, contributions and repertoire], vol. I, pp. 543-572, Basilica, Bucureşti.

Buda, D., 2016, 'Rolul monahilor în formarea spirituală a credincioșilor potrivit lucrării Historia religiosa $(\mathrm{H}$. rel.) a lui Teodoret al Cyrului [The role of monks in the
spiritual formation of believers according to Historia religiosa $(\mathrm{H}$. rel.) of Theodoret of Cyrus]', in V. Stanciu \& C. Sonea (eds.), Misiunea parohiei și a mănăstirii într-o of Cyrus]', in V. Stanciu \& C. Sonea (eds.), Misiunea parohiei și a mănastirii într-o
lume în continuă schimbare [The mission of the parish and the monastery in a lume în continuă schimbare [The mission of the parish and the monastery
constantly changing world], vol. I, pp. 415-432, Renașterea, Cluj-Napoca.

Chifăr, N., 2014, 'Monahismul slav răsăritean [Eastern Slavic monasticism]', in M. Păcurariu \& N. Edroiu (eds.), Monahismul ortodox românesc: Istorie, contribuţii şi repertorizare [Romanian Orthodox monasticism: History, contributions and repertoire], vol. I, pp. 179-207, Basilica, Bucureşti. 
Ică, Jr. I., 2004, 'Il Roveto Ardente una fioritura dell' ideale esicasta all'alba de communismo in Romania', in M. Bielawski \& D. Hombergen (eds.), /l monachesimo tra eredità e aperture: Atti del simposio 'Testi e Temi nella Tradizione del tra eredità e aperture: Atti del simposio 'Testi e Temi nella Tradizione del Monachesimo Cristiano': Per il 50: Anniversario dell'Istituto Monastico di
Sant'Anselmo, Roma, 28 maggio - 1, giugno 2002 (Studia Anselmiana 140 Analectica monastica 8), pp. 471-488, Roma.

lelciu, M., 2008, T̂nțelepciunea duhovnicească sau discernământul, în viziunea Sf Ioan Scărarul [Spiritual wisdom or discernment, in the vision of St. John Klimax]', in M. lelciu (ed.), Patristică și Actualitate. Omagiu P.C. Arhid. Prof. Univ. Dr. Constantin Voicu, la împlinirea a 75 de ani de viață [Patristic and actuality: Tribute to Constantin Voicu, on his 75th birthday], pp. 222-236, Andreiana, Sibiu.

Oancea, C., 2006, 'Auslegungen zu 1 Kön 17-18 in der altchristlichen Literatur', Sacra Scripta 4(1-2), 7-25.

Scrima, A., 1996, Timpul Rugului Aprins. Maestrul spiritual în tradiţia răsăriteană [The age of the burning bush: The spiritual master in the eastern tradition], Humanitas, Bucureşti.

Scrima, A., 2003, Despre isihasm [On hesychasm], Humanitas, Bucureşti.
Scrima, A., 2004, Duhul Sfânt si Unitatea Bisericii: 'Jurnal' de Conciliu [The Holy Spirit and the unity of the church: 'Journal' of the council], Anastasia, Bucureşti.

Scrima, A., 2008, Ortodoxia şi încercarea comunismului [Orthodoxy and the test of communism], Humanitas, Bucureşti.

Scrima, A., 2017, T̂n miezul tainei unităţii: Monahul [Inside the mystery of unity: The monk]', in E. Poirot \& A. Ioniţă (eds.), Monahismul cresstin în actualitate [Christian monasticism today], pp. 21-48, Andreiana/PUC, Sibiu/Cluj-Napoca.

Streza, C., 2015, 'The monk as bishop: Civic patriotism and social devotion in the 4th century Cappadocia', in J.A. McGuckin (ed.), Asceticism Monasticism and holiness in Eastern Orthodox Christianity (Sophia studies in Orthodox Theology), vol. 7 pp. 75-98, Theotokos Press, New York, NY.

Thunberg, L., 1999, Omul și cosmosul în viziunea Sfântului Maxim Mărturisitoru [Man and the cosmos in the vision of Saint Maximus the Confessor], EIBMBOR, Bucureşti.

Tofan, I.-A., 2019, Omul lăuntric. André Scrima şi fizionomia experienţei spirituale, Humanitas, Bucureşti

Toroczkai, C., 2016, 'Orthodox spirituality in the twentieth century: A brief survey', Studia Monastica 58(2), 401-409. 